\title{
ВЕГЕТАТИВНА ДИСФУНКЦІЯ У ХВОРИХ НА ВІЛ-ІНФЕКЦІЮ, ЯКІ ПЕРЕБУВАЮТЬ НА АНТИРЕТРОВІРУСНІЙ ТЕРАПІЇ: ДОСЛІДЖЕННЯ ВАРІАБЕЛЬНОСТІ СЕРЦЕВОГО РИТМУ
}

\author{
Буковинський державний медичний університет
}

Проаналізовано динаміку змін часових і спектральних параметрів варіабельності серцевого ритму у 44 ВІЛ-інфрікованих хворих, які отримують високоактивну антиретровірусну терапію та терапію, доповнену донатором оксиду азоту - молсидоміном. Показано, що додаткове включення молсидоміну в комплексне лікування хворих з ВІЛ-інфекцією сприяє відновленню вегетативного балансу за рахунок зменшення симпатикотонії.

Ключові слова: ВІЛ-інфекція, варіабельність серцевого ритму, високоактивна антиретровірусна терапія, молсидомін.

Вегетативна дисфункція серед ВІЛ-інфікованих осіб спостерігається значно частіше, порівняно з населенням у цілому [1-4]. Точний механізм, за допомогою якого ВІЛ впливає на фрункцію вегетативної нервової системи, залишається нез'ясованим, проте може включати ВІЛіндуковані зміни у головному мозку. Вірус імунодефіциту людини володіє тропністю до клітин центральної нервової системи та у високій концентрації локалізується у гіпокампі, базальних гангліях і гіпоталамусі - ділянках, що забезпечують регуляцію вегетативних фрункцій [5]. Експериментально підтверджено, що внутрішньошлуночкова ін'єкція gр120 - білка оболонки ВІЛ у щурів спричиняє порушення фрункції супрахіазматичного ядра в гіпоталамусі, що, в свою чергу, сприяє підвищенню рівня симпатичної активності [6]. Бразильські вчені, вивчаючи морфологію симпатичних гангліїв ВІЛінфрікованих пацієнтів з термінальною стадією захворювання, виявили скупчення запальних клітин та ознаки дегенерації нейронів у вузлах [7]. Найімовірнішою причиною загибелі цих клітин була цитопатична дія gр120 та нейротоксичних речовин, які продукуються клітинами мікроглії, астроцитами і моноцитами, що свідчить про залучення автоімунних механізмів [8].

Порушення фрункції ендотелію при ВІЛ-інфрекції також відіграє важливу патогенетичну роль у розвитку вегетативного дисбалансу. Ендотеліальна дисфункція, якій притаманне зниження вивільнення NO, є важливою у зміні судинного тонусу та у модуляції активності симпатичної нервової системи [9, 10].

Ефективна антиретровірусна терапія (АРТ) сприяє зниженню поширеності вегетативної дисфункції у популяції ВІЛ-інфрікованих хворих. Так, ВІЛ-інфріковані особи, які отримували антиретровірусну терапію, мали кращі показники вегетативного забезпечення серцевої діяльності порівняно з хворими, які не перебували на етіотропній терапії [2]. Разом з тим, АРТ індукує безліч побічних ефектів, у тому числі дисліпідемію та резистентність до інсуліну [11-13]. Саме порушення ліпідного обміну та діабетогенний ефект АРТ можуть сприяти розвитку автономної нейропатії серця. При гіперглікемії за градієнтом концентрації глюкоза засвоюється клітинами гіпоталамуса, що призводить до розгальмування симпатичних центрів стовбура головного мозку та підвищення активності симпатичної ВНС. Високий рівень інсуліну збільшує поглинання та обмін глюкози в інсуліночутливих клітинах гіпоталамуса з наступною активацією центральних механізмів симпатичної ВНС та збільшенням виділення катехоламінів у периферичних нервових закінченнях симпатичної нервової системи 3 розвитком виразної тканинної гіперсимпатикотонії [14]. $€$ й докази того, що інгібітори протеаз (ІП) безпосередньо перешкоджають поглинанню глюкози інсулін-чутливими тканинами шляхом селективного пригнічення переносника глюкози GLUT4 [15]. GLUT4 знаходять і в нейронах ядер гіпоталамуса, який регулює функції автономної нервової системи. Також інгібітори протеаз можуть безпосередньо впливати на вегетативну нервову систему через механізм протеази, оскільки здатні пригнічувати протеаз-активовані рецептори (PAR-2 та PAR-3), локалізовані в таламусі, гіпоталамусі та смугастому тілі [6]. Крім того, деякі противірусні препарати, зокрема нуклеозидні інгібітори зворотної транскриптази, пов'язані 3 розвитком токсичної нейропатії [16].

Мета дослідження - вивчити стан вегетативного забезпечення серцевої діяльності хворих на ВІЛ- 
інсекцію, які перебувають на антиретровірусній терапії, проаналізувати динаміку змін часових та спектральних параметрів варіабельності серцевого ритму у ВІЛінорікованих пацієнтів на фроні лікування молсидоміном.

\section{Пацієнти і методи}

Обстежено 44 хворих на ВІЛ-інфекцію, які перебували на амбулаторному спостереженні протягом 2013-2014 pр. в обласному центрі профрілактики та боротьби зі СНІДом м. Чернівці. Серед зазначених пацієнтів - 21 чоловік і 23 жінки, віком від 21 до 42 років. Середній вік пацієнтів становив $(28,4 \pm 0,4)$ року.

Діагноз ВІЛ-інфекції був встановлений на підставі епідеміологічного анамнезу, клінічних даних і підтверджений виявленням специфічних антитіл до ВІЛ у реакції імуноферментного аналізу і в реакції імунного блотингу.

Серед обстежених було 23 (52,3 \%) хворих з III та 21 (47,7 \%) пацієнт 3 IV клінічною стадією ВІЛ-інфекції. При встановленні діагнозу брали до уваги клініко-епідеміологічні дані та результати лабораторних методів дослідження: серологічного та імунологічного (у т.ч. визначення вмісту CD4+-лімсроцитів). Рівень CD4+-лімсроцитів досліджували після зникнення симптомів супутнього гострого інфекційного захворювання (не менше як через 4 тижні).

Всі обстежені особи отримували схеми високоактивної антиретровірусної терапії (ВААРТ) першого ряду, рекомендовані в Україні: 26 осіб (59,1%) перебували на схемах, які ґрунтуються на нуклеозидних і ненуклеозидних інгібіторах зворотної транскриптази (АZT-3TC-EFV) та 18 (40,9%) на нуклеозидних інгібіторах зворотної транскриптози та посиленому інгібіторі протеаз (AZT-3TC-LPV/r). Зазначене лікування доповнювали молсидоміном по 1 таблетці (2 мг) 3 рази на добу після їжі 13 особам, які перебували у III, та 11 - у IV клінічній стадії. Решта (10 хворих перебували у III і стільки ж - у IV клінічній стадії ВІЛ-інфекції) отримували тільки антиретровірусну терапію.

Групу порівняння склали 30 здорових осіб, які за статтю й віком були цілком зіставні з представниками досліджуваних груп.

Всі пацієнти обстежені відповідно до наказу МОЗ України № 551 від 12.07.2010 р. «Клінічний протокол антиретровірусної терапії ВІЛ-інфекції у дорослих та підлітків» [17].

Стан вегетативної регуляції серцевого ритму визначали за допомогою комп'ютерної кардіоінтервалометрії із застосуванням монітору артеріального тиску та електрокардіосигналів добового SDM23. Дослідження варіабельності серцевого ритму (ВСР) проводили в ранкові години, натще, після 15-хвилинного перебування пацієнта в кліностазі. ЕКГ записували протягом 5 хвилин. Дані ЕКГ автоматично оброблялися з визначенням часових і спектральних показників ВСР, що дозволило здійснити їх детальний аналіз відповідно до протоколу робочої групи Європейського то- вариства кардіології й Північноамериканського товариства кардіостимуляції та електрофрізіології [18].

Аналізували такі часові показники ВСР (Time Domain Methods): RRNN - середня тривалість інтервалів RR (мc); SDNN - стандартне відхилення нормальних інтервалів RR (мc); rMSSD - стандартне (середньоквадратичне) відхилення різниці послідовних інтервалів RR (мc); pNN50 - відсоток послідовних інтервалів RR, різниця між якими перевищує 50 мс (\%). Показники rMSSD та pNN50 відображають швидкі високочастотні коливання в структурі ВСР і демонструють високу кореляцію. За нормалізований інтервал NN уважали інтервал RR між сусідніми шлуночковими комплексами, викликаними деполяризацією синусового вузла. Спектральний аналіз проводили з оцінкою: ТР - загальної потужності всіх інтервалів RR (Mc²); VLF - потужності в діапазоні дуже низьких частот (0,003-0,040 Гц) (мc²); LF - потужності в діапазоні низьких частот (0,04-0,15 Гц) (мс²) та LFnorm - потужності спектра на частоті 0,04-0,15 Гц, вираженої в нормалізованих одиницях (н.о.), що розраховуються за фрормулою LFnorm=LF/(TP-VLF)·100 \%; HF - потужності в діапазоні високих частот (0,15-0,40 Гц) (мс $\left.{ }^{2}\right)$ та HFnorm - потужності спектра на частоті 0,15-0,40 Гц, вираженої в н.о., що розраховуються за формулою HFnorm=HF/(TP-VLF)·100 \%; LF/HF - співвідношення низькочастотної і високочастотної складових спектра як показник балансу симпатичного та парасимпатичного відділів ВНС [19-21].

\section{Результати досліджень та їх обговорення}

В обстежених нами ВІЛ-інфрікованих пацієнтів на фроні високоактивної антиретровірусної терапії дещо покращився стан вегетативного забезпечення серцевої діяльності (табл. 1). Зазначимо, що позитивних змін зазнавали як показники симпатичної ланки ВНС, так і вагусної модуляції серцевого ритму. Як наслідок, спостерігалась тенденція до зменшення симпатикотонії. Проте, незважаючи на лікування антиретровірусними препаратами протягом 3 міс., досліджувані показники вегетативної диссункції суттєво відрізнялися від значень здорових осіб ( $p<0,05)$. Отже, у ВІЛ-позитивних пацієнтів, незважаючи на адекватне зниження вірусного навантаження на фроні використання ВААРТ, спостерігаються ознаки вегетативної диссрункції.

У пацієнтів, які перебували на антиретровірусній терапії на основі посиленого інгібітора протеаз, спостерігалися дещо гірші показники фрункціонального стану вегетативної нервової системи, проте не на статистично достовірному рівні. Крім того, кореляційний аналіз не показав жодних статистично значущих зв'язків між застосуванням ІП та порушенням вегетативного забезпечення серцевої діяльності.

Отримані нами дані перегукуються з дослідженнями зарубіжних вчених. Так, автори з Данії [22] оцінювали 
поширеність вегетативної диссрункції в популяції ВІЛпозитивних хворих, які перебували на антиретровірусній терапії. Результати цього дослідження показали, що у пацієнтів з ВІЛ-інфекцією частота серцевих скорочень у спокої була значно вищою ( $<<0,001)$, тоді як показники часового аналізу ВСР достовірно нижчі $(p<0,05-0,01)$ порівняно з групою здорових добровольців. Серед спектральних параметрів суттєво відрізнявся лише показник низькочастотних коливань (LF) ( $<<0,01)$, проте не було жодних відмінностей між групами в показниках частки симпатичних впливів (LFnorm) у загальному спектрі вегетативної регуляції. Дослідники пояснили достовірне зменшення LF складової спектру у ВІЛ-позитивних осіб нижчою загальною потужністю вегетативної регуляції, а не зменшенням симпатичної модуляції серцевого ритму. Спостерігалась тенденція до зниження потужності високочастотних хвиль (HF) (p=0,2), проте ризик статистичної помилки другого роду був істотним через невелику кількість обстежених пацієнтів (16 ВІЛ-інфрікованих і 12 осіб групи контролю). Отже, загальна картина чітко вказує на наявність парасимпатичної дисфункції у ВІЛ-інфрікованих хворих, які перебувають на антиретровірусній терапії. Жодних кореляцій між вегетативними параметрами та тривалістю недуги чи противірусної терапії, рівнем CD4+лімфоцитів не було знайдено. Зважаючи на те, що це дослідження є крос-секційним, автори не могли точно визначити чи вегетативна дисорнкція була індукована антиретровірусною терапією або була присутня ще до початку терапії.

Askgaard G. та співавтори [16] також виявили вегетативну диссункцію у ВІЛ-позитивних пацієнтів на високоактивній антиретровірусній терапії з пригніченим вірусним навантаженням. Автори зафріксували достовірне зниження RRNN, тобто зростання частоти серцевих скорочень у спокої порівняно з ВІЛ-негативним контролем. Крім того, суттєво меншими були значення SDNN, що вказувало на загальне зниження варіабельності серцевого ритму у ВІЛ-інфрікованих. Інші показники часового аналізу між групами не відрізнялися. У цьому дослідженні не було знайдено жодної кореляції між показниками ВСР та тривалістю ВІЛ-інфекції, рівнем вірусного навантаження чи імунного захисту та тривалістю етіотропного лікування. Не виявили статистично вірогідної різниці між порушенням стану вегетативного забезпечення серцевої діяльності у хворих на ВІЛ-інфекцію та включенням до режиму АРТ інгібіторів протеаз або абакавіру. Тим не менше, вегетативна дисорунція корелювала з високим рівнем глюкози (глікований гемоглобін), а також з гіперхолестеринемією.

Американські дослідники [23] також представили дані, які показують, що ВІЛ-позитивні особи, незалежно від того, чи вони отримують інгітори протеази або схеми
APT на основі інших препаратів, мають порушення відновлення ЧСС після виконання вправ на велоергометрі.

SMART дослідження [24] показало, що використання схем APT на основі IП на противагу ННІЗТ позитивно впливає на стан вегетативного забезпечення серцевої діяльності ВІЛ-інфікованих: зменшує частоту серцевих скорочень та підвищує параметри варіабельності серцевого ритму. Проте такі висновки не стосуються схем на основі посиленого інгібітора протеаз. Відмінності у впливі різних схем лікування на показники ВСР можуть бути пов'язані з різницею у балансі між їхнім сприятливим ефектом - вірусологічним пригніченням і шкідливим впливом - атерогенною дією. І в цьому дослідженні також жодних статистично достовірних зв'язків між рівнем CD4+-клітин, РНК ВІЛ і показниками вегетативної дисорунції не було знайдено.

Цікавим є дослідження бразильських науковців [25], які порівняли показники варіабельності серцевого ритму 29 ВІЛ-інфрікованих пацієнтів, що отримували АРТ, 28 АРТ-наївних хворих з даними ВІЛ-негативних осіб 3 цукровим діабетом і здорових добровольців. Жодної різниці в параметрах time domain серед груп не було. Тоді як параметр частки симпатичних впливів (LFnorm) був достовірно знижений, а частки вагусних впливів (HFnorm) у загальному спектрі вегетативної регуляції підвищеній у ВІЛ-інфікованих пацієнтів, які не отримують противірусну терапію ( $<<0,05)$, та в осіб з цукровим діабетом $(p<0,01)$ порівняно з групою контролю. АРТ-наївні ВІЛ-інфіковані пацієнти $(p<0,05)$ та хворі на цукровий діабет $(p<0,01)$ відповідно мали суттєво нижчі показники індексу симпато-парасимпатичного балансу (LF/ HF) порівняно зі здоровими особами. Зважаючи на те, що показники вегетативної дисфрункції ВІЛ-інсрікованих пацієнтів, які перебували на антиретровірусній терапії, мали середнє значення між параметрами АРТ-наївних та групи контролю, а також статистично вірогідно не відрізнялись від показників здорових людей, вчені дійшли висновку, що високоактивна антиретровірусна терапія позитивно впливає на перебіг ВІЛ-інфекції та зменшує вегетативний дисбаланс.

Включення до противірусної терапії обстежених пацієнтів молсидоміну забезпечило значне зменшення проявів кардіоваскулярної нейропатії порівняно 3 пацієнтами до лікування, як за рахунок збільшення вагусної - $3(393,9 \pm 34,1)$ до $(595,4 \pm 37,8)$ мс $^{2}$ при III та $3(338,7 \pm 39,2)$ до $(491,9 \pm 36,7)$ мс $^{2}$ при IV клінічній стадії ВІЛ-інфрекції ( $<<0,05)$, так і симпатичної модуляції серцевого ритму - показник зріс $3(635,7 \pm 41,3)$ до $(780,4 \pm 43,1)$ мс $^{2}$ та $3(597,9 \pm 41,7)$ до $(723,1 \pm 43,7)$ мс $^{2}$ за відповідних стадій ( $<0,05)$, яка однаково залишилася домінуючою. Зменшився й індекс симпатопарасимпатичного балансу, проте не на статистично 
достовірному рівні. Щоправда, збереження достовірної різниці між пацієнтами на апробованій терапії та групою контролю не дозволяє говорити про нормалізацію показників варіабельності серцевого ритму $(p<0,05)$. Відзначимо, що врівноважилися лише показники частки симпатичних (LFnorm) - за III клінічної стадії до рівня $(56,77 \pm 0,87)$ н.о., а за IV - $(58,91 \pm 0,83)$ н.о. та параметру частки вагусних впливів (HFnorm) - до $(43,23 \pm 0,89)$ та $(41,09 \pm 0,78)$ н.о за III та IV стадій ВІЛінорекції у загальному спектрі вегетативної регуляції і, відповідно, - індексу вегетативного балансу (LF/HF) до $(1,36 \pm 0,17)$ та $(1,46 \pm 0,16)$ (табл. 1$)$.

Таблиця 1

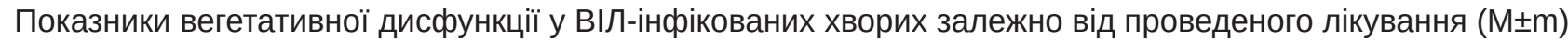

\begin{tabular}{|c|c|c|c|c|c|c|c|}
\hline \multirow{3}{*}{ Показник } & \multirow{3}{*}{$\begin{array}{c}\text { Здорові } \\
\text { особи } \\
\text { (контроль), } \\
\text { n=30 }\end{array}$} & \multicolumn{6}{|c|}{ Клінічна стадія ВІЛ-інфекції } \\
\hline & & \multicolumn{2}{|c|}{$\begin{array}{c}\text { при першому обстеженні, } \\
\text { n=44 }\end{array}$} & \multicolumn{2}{|c|}{ через 3 міс. ВАAРT, n=20 } & \multicolumn{2}{|c|}{ через 3 міс. ВААРТ + молсидомін, n=24 } \\
\hline & & III, $n=23$ & $\mathrm{IV}, \mathrm{n}=21$ & III, $\mathrm{n}=10$ & $\mathrm{IV}, \mathrm{n}=10$ & $\mathrm{III}, \mathrm{n}=13$ & $\mathrm{IV}, \mathrm{n}=11$ \\
\hline SDNN, MC & $112,30 \pm 2,31$ & $87,22 \pm 2,14$ * & $82,86 \pm 1,88$ * & $89,30 \pm 1,87$ * & $83,70 \pm 1,71$ * ** & $90,77 \pm 1,76$ * & $84,91 \pm 1,76$ * ** \\
\hline rMSSD, MC & $36,43 \pm 0,97$ & $30,74 \pm 1,02$ * & $24,29 \pm 1,07$ * ** & $32,50 \pm 0,89$ * & $26,10 \pm 0,87$ * ** & 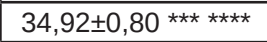 & $28,09 \pm 0,81 * \star * \star \star \star *$ \\
\hline pNN50, \% & $22,63 \pm 0,95$ & $15,35 \pm 1,29 *$ & $11,19 \pm 1,48$ * ** & $16,90 \pm 1,21$ * & $13,70 \pm 1,17$ * & $19,69 \pm 1,28$ *** & $15,73 \pm 1,14$ ****** \\
\hline $\mathrm{TP}, \mathrm{MC}^{2}$ & $2518,7 \pm 129,0$ & $1945,3 \pm 59,6$ * & $1796,5 \pm 39,3$ *** & $2083,1 \pm 63,8$ * & $1869,7 \pm 54,9$ *** & $2142,1 \pm 59,5 * * * *$ & $1973,8 \pm 60,8$ **** \\
\hline VLF, $\mathrm{MC}^{2}$ & $825,1 \pm 44,1$ & $624,4 \pm 40,9$ * & $588,2 \pm 41,8$ * & $687,2 \pm 40,6$ * & $631,8 \pm 42,9$ * & 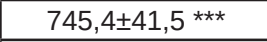 & $694,5 \pm 43,1$ * \\
\hline $\mathrm{LF}, \mathrm{MC}^{2}$ & $897,6 \pm 38,5$ & $635,7 \pm 41,3$ * & $597,9 \pm 41,7^{*}$ & $759,8 \pm 45,6$ **** & $704,1 \pm 46,2$ * & $780,4 \pm 43,1^{* * * \star}$ & $723,1 \pm 43,7^{* * \star \star}$ \\
\hline LFnorm, H.O & $56,43 \pm 1,18$ & $61,74 \pm 0,83$ * & $62,57 \pm 0,87$ * & $60,20 \pm 0,84$ * & $61,30 \pm 0,83$ * & 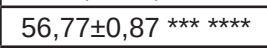 & $58,91 \pm 0,83$ ******* \\
\hline $\mathrm{HF}, \mathrm{MC}^{2}$ & $694,1 \pm 30,4$ & $393,9 \pm 34,1$ * & $338,7 \pm 39,2$ * & $492,6 \pm 34,8$ **** & $425,9 \pm 36,2$ * & 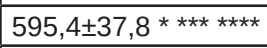 & $491,9 \pm 36,7^{* * \star \star}$ \\
\hline HFnorm, H.O & $43,57 \pm 1,16$ & $38,26 \pm 0,86$ * & $37,43 \pm 0,84$ * & $39,80 \pm 0,84$ * & $38,70 \pm 0,86$ * & 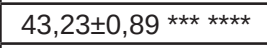 & 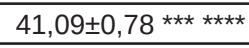 \\
\hline LF/HF, од. & $1,31 \pm 0,08$ & $1,65 \pm 0,15^{*}$ & $1,71 \pm 0,12$ * & $1,58 \pm 0,13$ & $1,62 \pm 0,15$ & $1,36 \pm 0,17$ & $1,46 \pm 0,16$ \\
\hline
\end{tabular}

Примітки: * - достовірна різниця порівняно зі здоровими особами $(\mathrm{p}<0,05) ;{ }^{*}$ - з ВІЛ-інсрікованими пацієнтами у ІІІ клінічній стадії $(p<0,05) ;{ }^{* \star *}$ - з відповідним показником при першому обстеженні у межах відповідної клінічної стадії ВІЛ-інфрекції $(p<0,05) ;{ }^{* \star *}-3$ пацієнтами, які отримували лише антиретровірусну терапію $(p<0,05)$.

Зіставивши показники вегетативної дисоункції пацієнтів, які перебували на антиретровірусній терапії, доповненій донатором оксиду азоту, з відповідними даними у групі хворих, які отримували лише високоактивну атриретровірусну терапію, виявили за III клінічної стадії статистично вагоме підвищення rMSSD $(p<0,05)$, HF $(p<0,05)$ HFnorm $(p<0,05)$, та зниження LFnorm $(p<0,05)$, тоді як за IV стадії - лише статистично вагоме підвищення HFnorm $(p<0,05)$ та, відповідно, зниження LFnorm $(p<0,05)$ (табл.).

Отже, застосування молсидоміну у хворих на ВІЛінорекцію сприяє відновленню балансу симпатичної та парасимпатичної регуляції серцевої діяльності, зменшенню симпатикотонії. Такий його вплив можна пояснити тим, що активним метаболітом молсидоміну $€$ лінсидомін, який спонтанно звільняє закис азоту, що й забезпечує властивості препарату як його донатора, а отже молсидомін здатний впливати на нейроендокринну регуляцію, зокрема на орункцію $\mathrm{BHC}$, за рахунок NO-залежного ефекту, що призводить до збільшення вагусного впливу та пригнічення симпатичного компоненту.

\section{Висновки}

1. У ВІЛ-позитивних пацієнтів, незважаючи на адекватне зниження вірусного навантаження на фроні використання високоактивної антиретровірусної терапії, спостерігаються ознаки вегетативної диссрункції.

2. Доповнення противірусної терапії молсидоміном позитивно впливає на перебіг ВІЛ-інфекції, зменшуючи симпатичний та збільшуючи парасимпатичний впливи вегетативної нервової системи на серце та нормалізуючи його біорефлекторну регуляцію.

Результати проведених досліджень обґрунтовують перспективу наукового пошуку щодо вивчення зв'язку між рівнем вірусологічного пригнічення та показниками функціонального стану вегетативної нервової системи у хворих на ВІЛ-інфекцію, що отримують високоактивну антиретровірусну терапію.

\section{Література}

1. Compostella C. Cardiovascular autonomic neuropathy in HIV-positive african patients / C. Compostella, L. Compostella, R. D'Elia // Minerva cardioangiologica. - 2008. - Vol. 56. - P. 417-428.

2. Power spectral analysis of heart rate variability in HIVinfected and AIDS patients / [D. Correia, D.E. Rodrigues, L.A. Resende et al.] // PACE. - 2006. - Vol. 29. - P. 53-58.

3. Autonomic dysfunction as a predictor of heart disease in human immunodeficiency virus (HIV) / [Y. Elnahar, M. Bisharat, J. Daoko et al.] // J. AIDS HIV Res. - 2013. - Vol. 5, N 1. - P. 1-11.

4. Heart rate variability and autonomic function tests in HIV positive individuals in India / [A. Sakhuja, A. Goyal, A.K. Jaryal et al.] // Clin. Auton. Res. - 2007. - Vol. 17, N 3. - P. 193-196. 
5. Yun A.J. Modulation of host immunity by HIV may be partly achieved through usurping host autonomic functions / A.J. Yun, P.Y. Lee, K.A. Bazar // Med Hypotheses. - 2004. - Vol. 63. - P. 362-366.

6. Cardiovagal autonomic function in HIV-infected patients with unsuppressed HIV viremia / [D.C. Chow, R. Wood, J. Choi et al.] // HIV Clin. Trials. - 2011. - Vol. 12, N 3. - P. 141-150.

7. Chimelli L. Degenerative and inflammatory lesions in sympathetic ganglia: further morphological evidence for an autonomic neuropathy in AIDS / L. Chimelli, A. R. Martins // J. NeuroAIDS. - 2002. - Vol. 2. - P. 67-82.

8. Запорожан В.М. ВІЛ-інфекція і СНІД / В.М. Запорожан, М.Л. Аряєв. - К.: Здоров'я, 2004. - 636 с.

9. Malpas S.C. Sympathetic nervous system overactivity and its role in the development of cardiovascular disease / S.C. Malpas // Physiol Rev. - 2010. - Vol. 90. - P. 513-517.

10. Ramchandra R. Nitric oxide and sympathetic nerve activity in the control of blood pressure / R. Ramchandra, C.J. Barret, S.C. Malpas // Clin. Exp. Pharmacol. Physiol. - 2005. - Vol. 32, N 5-6. - P. 440-446.

11. Prevalence of metabolic syndrome in HIV infected patients receiving highly active antiretroviral therapy using International Diabetes Foundation and adult treatment panel III criteria / [K. Samaras, H. Wand, M. Law et al.] // Diabetes Care. - 2007. - Vol. 30. - P. 113119

12. Metabolic syndrome, cardiovascular disease and type 2 diabetes mellitus after initiation of antiretroviral therapy in HIV infection / [H. Wand, A. Calmy, D.L. Carey et al.] // AIDS. - 2007. - Vol. 21, N 18. - P. 2445-2453.

13. Effects of HIV infection and antiretroviral therapy on the heart and vasculature / [M.P. Dubé, S.E. Lipshultz, C.J. Fichtenbaum et al.] // Circulation. - 2008. - Vol. 118. - P. e36-e40.

14. Старкова Н.Т. Метаболический синдром инсулинорезистентности: основная концепция и следствие: обзор / Н.Т. Старкова, И.В. Дворяшина // Терапевт. арх. - 2004. - № 10. - С. 54-58.

15. Лечение ВИЧ-инфекции / [М. Альтфельд, Г. Беренс П. Браун и др.]; под. ред. К. Хоффрман, Ю.К. Рокштро. - М.: Р. Валент, 2012. - 736 с.

16. Decreased heart rate variability in HIV positive patients receiving antiretroviral therapy: importance of blood glucose and cholesterol / [G. Askgaard, U.S. Kristoffersen, J. Mehlsen et al.]. // PLOS ONE. - 2011. - Vol. 6. - P. e20196.

17. Клінічний протокол антиретровірусної терапії ВІЛ-інфекції у дорослих та підлітків. - Затверджено наказом МОЗ України № 551 від 12.07.2010 р.: http://mozdocs.kiev.ua/view.php?id=11177.

18. Task Force of the European Society of Cardiology and the North American Society of Pacing and Electrophysiology. Heart rate variability: standards of measurement, physiological interpretation and clinical use // Circulation. - 1996. - Vol. 93 - P. 1043-1065.
19. Жарінов О.Й. Дослідження варіабельності ритму серця: чи з'являться нові узгоджені рекомендації? / О.Й. Жарінов У.П. Черняга-Ройко // Укр. кардіол. журн. - 2007. - № 6. - С. 98102.

20. Бокерия Л.А. Вариабельность сердечного ритма: методы измерения, интерпретация, клиническое использование Л.А. Бокерия, О.Л. Бокерия, И.В. Волковская // Анналы аритмологии. - 2009. - № 4. - С. 21-32.

21. Яблучанский Н.И. Вариабельность сердечного ритма в помощь практическому врачу / Н.И. Яблучанский, А.В. Мартыненко. - Харьков, 2010. - 131 с.

22. Autonomic dysfunction in HIV patients on antiretroviral therapy: studies of heart rate variability / [A. Lebech, U.S. Kristoffersen, J. Mehlsen et al.] // Clin. Physiol. Funct. Imaging. - 2007. - Vol. 27. P. 363-367.

23. Post-exercise heart rate recovery in HIV-positive individuals on highly active antiretroviral therapy. Early indicator of cardiovascular disease? / [W.T. Cade, D.N. Reeds, S. Lassa-Claxton et al.]. // HIV Med. - 2008. - Vol. 9. - P. 96-100.

24. Protease inhibitors and cardiac autonomic function in HIVinfected patients: a cross-sectional analysis from the Strategies for Management of Antiretroviral Therapy (SMART) Trial / [E.Z. Soliman, M.P. Roediger, D.A. Duprez et al.] // BMJ Open. - 2013. - Vol. 3. P. e002523.

25. Heart rate variability in HIV patients, diabetics, and controls: The AGATAA Study / [I.M. Bensenor, M. Eira, E.L. Dorea et al.] // ISRN Vascular Medicine. - 2011. - Article ID 876864, 8 p.

\section{AUTONOMIC DYSFUNCTION IN PATIENTS WITH HIV-INFECTION RECEIVING ANTIRETROVIRAL THERAPY: STUDY OF HEART RATE VARIABILITY}

Kh.I. Vozna, V.D. Moskaliuk

SUMMARY. The dynamics of changes in time and spectral parameters of heart rate variability in $44 \mathrm{HIV}$ infected patients are analizyed in the article. The patients received highly active antiretroviral therapy and treatment, complete with nitric oxide donor - molsydomin. It is shown that the additional inclusion of molsydomin in treatment of HIV-infected patients helps to restore autonomic balance by reducing sympathicotonia.

Key words: HIV-infection, heart rate variability, highly active antiretroviral therapy, molsydomin.

Отримано 4.05.2016 p. 